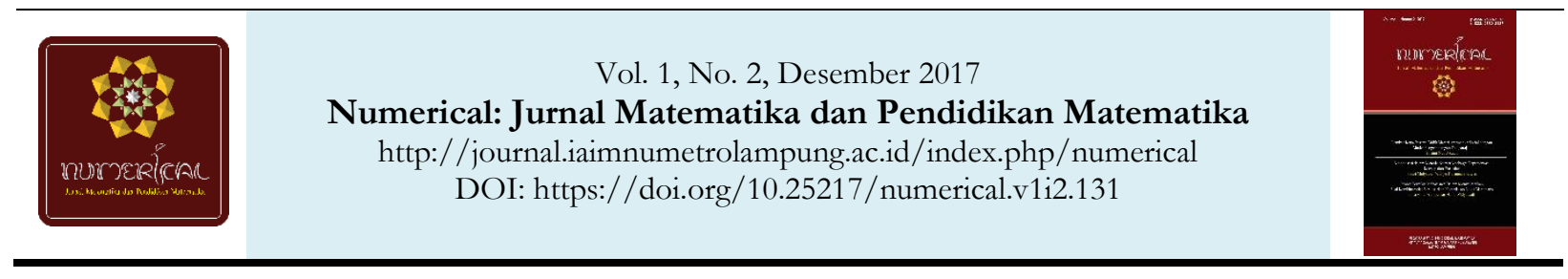

\title{
Efektivitas Pembelajaran Berbasis Schoology
}

\author{
Choirudin $^{1}$ \\ 1) Institut Agama Islam Ma'arif NU (IAIMNU) Metro Lampung \\ Correspondence: $\triangle$ choirudiniaimnumetro@gmail.com
}

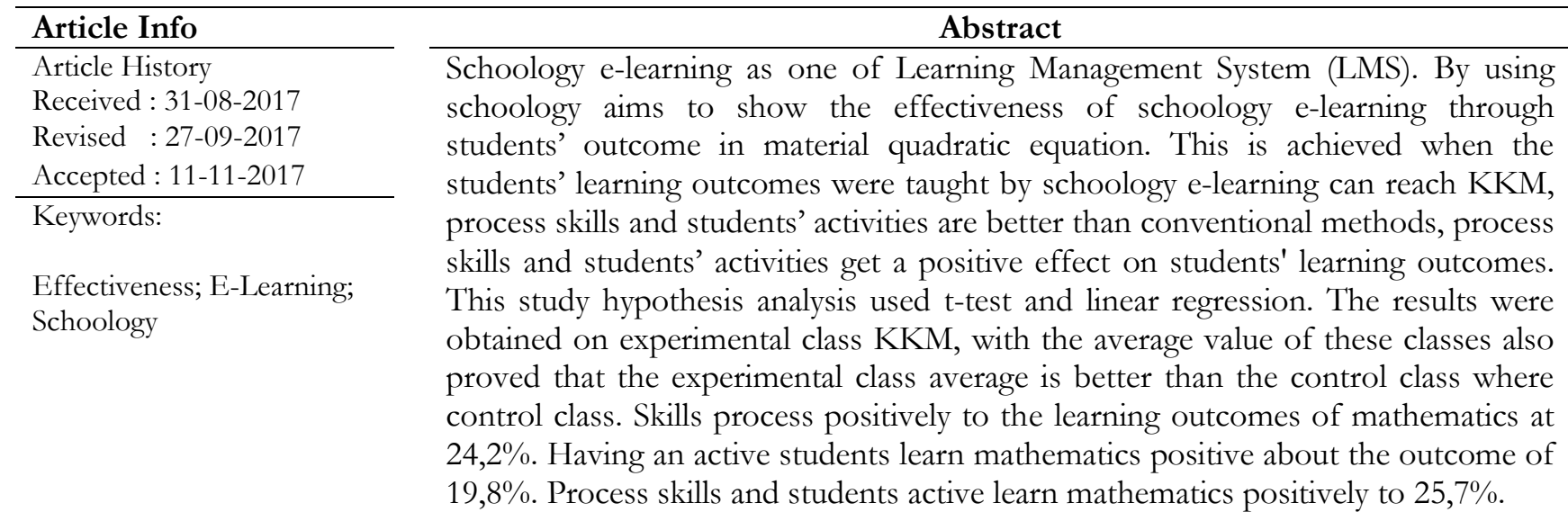

\section{PENDAHULUAN}

Seiring dengan perkembangan teknologi informasi yang semakin pesat, kebutuhan akan suatu konsep dan mekanisme belajar mengajar berbasis TI menjadi tak terelakan lagi [1]. Perkembangan teknologi dan informasi ini dilandasi oleh perkembangan ilmu matematika [2]. Konsep yang kemudian terkenal dengan sebutan e-learning ini membawa pengaruh terjadinya proses transformasi pendidikan konvensional ke dalam bentuk digital, baik secara isi dan sistemnya. E-learning memberikan harapan baru sebagai alternatif solusi atas sebagian besar permasalahan pendidikan di Indonesia, dengan fungsi yang dapat disesuikan dengan kebutuhan, baik sebagai suplemen (tambahan), komplemen (pelengkap), ataupun substitusi (pengganti) atas kegiatan pembelajaran di dalam kelas yang selama ini digunakan.

E-learning adalah sebuah proses pembelajaran yang berbasis elektronik. Salah satu media yang digunakan adalah jaringan komputer. Dengan dikembangkannya jaringan komputer memungkinkan untuk dikembangkan proses belajar mengajar berbasis web, sehingga dapat dikembangkan ke jaringan komputer yang lebih luas yaitu internet, Sistem e-learning dengan menggunakan internet disebut juga internet enabled learning. Penyajian e-learning berbasis web ini bias menjadi lebih interaktif [3].

Yazdi [4] mendefinisikan e-learning sebagai sembarang pengajaran dan pembelajaran yang menggunakan rangkaian elektronik (LAN, WAN, atau internet) untuk menyampaikan isi pembelajaran, interaksi, atau bimbingan. Schoology merupakan bukti pesatnya perkembangan tekonologi internet yang ada [5]. Dapat disimpulkan bahwa Schoology adalah platform media sosial bagi guru dan siswa atau dosen dan mahasiswa yang berfungsi untuk berbagi ide, file, agenda kegiatan dan penugasan yang dapat menciptakan interaksi guru dan siswa. Sehingga Schoology memungkinkan bisa diterapkan sebagai media 
pembelajaran. Peran Schoology dalam dunia pendidikan adalah sebagai media pendukung yang dapat mengatasi permasalahan pembelajaran di kelas. Dengan media pendukung ini diharapkan dapat meningkatkan hasil belajar peserta didik. LMS atau yang lebih dikenal dengan Learning Management System adalah suatu perangkat lunak atau software untuk keperluan administrasi, dokumentasi, laporan sebuah kegiatan, kegiatan belajar mengajar dan kegiatan secara online (terhubung ke internet), e-learning dan materi-materi pelatihan, yang semuanya dilakukan dengan online. Salah satu LMS yang dirasa cocok digunakan untuk mendukung kegiatan pembelajaran adalah Schoology.

E-learning atau pembelajaran elektronik, merupakan salah satu bentuk dari aplikasi teknologi informasi dan komunikasi (TIK) dalam kegiatan pembelajaran. Clark Adrich menekankan e-learning pada kerangka berpikir penggunaan jaringan komputer. Ia menyatakan bahwa e-learning merupakan sebuah kombinasi antara proses, materi dan infrastruktur dalam penggunaan komputer dan jaringannya dalam rangka meningkatkan kualitas pada satu atau lebih bagian signifikan dari aspek-aspek rangkaian kegiatan pembelajaran, termasuk di antaranya adalah aspek manajemen dan aspek pendistribusian materi pelajaran[6]. Selanjutnya Victor Jeurissen mendefinisikan e-learning sebagai pengaplikasian teknologi dan model pembelajaran inovatif untuk mengubah cara individu atau organisasi dalam mengakses ilmu pengetahuan dan memperoleh keterampilan baru. The American Society for Training and Development (ASTD) berpendapat bahwa e-learning merupakan proses dan kegiatan penerapan pembelajaran berbasis web (web-based learning), pembelajaran berbasis komputer (computer based learning), pendidikan virtual (virtual education) dan/atau kolaborasi digital (digital collaboration). Materi-materi dalam kegiatan pembelajaran elektronik tersebut kebanyakan dihantarkan melalui media internet, intranet, tape, video atau audio, penyiaran melalui satelit, televisi interaktif dan CD-ROM. Definisi ini juga menyatakan bahwa definisi dari e-learning bisa bervariasi tergantung dari penyelenggara kegiatan e-learning tersebut dan bagaimana cara penggunaannya, termasuk juga apa tujuan penggunaannya [8]. Definisi ini juga menyiratkan simpulan yang menyatakan bahwa e-learning pada dasarnya adalah pengaplikasian kegiatan komunikasi, pendidikan dan pelatihan secara elektronik. E-learning adalah penggunaan teknologi komputer dan jaringan komputer yang disertai oleh penerapan model pembelajaran inovatif dalam rangka pelaksanaan kegiatan pembelajaran yang akan memberikan akses luas kepada peserta didik terhadap ilmu pengetahuan agar mereka bisa memperoleh keterampilan baru [8].

Metode pengajaran tradisional masih kurang efektif jika dibandingkan dengan metode pengajaran modern. Sistem e-learning diharapkan bukan sekedar menggantikan tetapi diharapkan pula untuk dapat menambahkan metode dan materi pengajaran tradisional seperti diskusi dalam kelas, buku, CD-ROM dan pelatihan komputer non internet. Elemen yang terdapat dalam sistem e-learning Prasojo sebagai berikut ini. 1) Soal-soal: materi dapat disediakan dalam bentuk modul, adanya soal-soal yang disediakan dan hasil pengerjaannya dapat ditampilkan. Hasil tersebut dapat dijadikan sebagai tolak ukur dan pelajar mendapatkan apa yang dibutuhkan; 2) Komunitas: para pelajar dapat mengembangkan komunitas online untuk memperoleh dukungan dan berbagi informasi yang saling menguntungkan; 3) Pengajar online: para pengajar selalu online untuk memberikan arahan kepada para pelajar, menjawab pertanyaan dan membantu dalam diskusi; 4) Kesempatan bekerja sama: Adanya perangkat lunak yang dapat mengatur pertemuan online sehingga belajar dapat dilakukan secara bersamaan atau real time tanpa kendala jarak; 5) Multimedia: penggunaan teknologi audio dan video dalam penyampaian materi sehingga menarik minat dalam belajar [9].

Proses belajar mengajar guru harus terampil memilih metode mengajar sehingga tujuan yang hendak dicapai dapat terlaksana dengan baik yakni hasil belajar yang maksimal, karena pemilihan metode di sini tiada lain adalah guna meningkatkan daya serap siswa terhadap pelajaran yang diberikan. 
Siswa dikatakan telah mengerti mengenai materi yang telah diajarkan atau belum dapat dilihat dari hasil tes yang diperoleh siswa. Tujuan dari belajar adalah untuk mendapatkan pengetahuan, penanaman konsep dan keterampilan serta pembentukan sikap. Untuk mendapatkan itu semua siswa harus belajar. Proses pembelajaran yang berlangsung tentu harus menyenangkan agar siswa mudah dalam menyerap pelajaran. Menurut Ningsih siswa yang memiliki kecemasan belajar akan mengalami kesulitan dalam memahami pelajaran [10]. Selanjutnya kecemasan yang berlebihan perlu adanya penanganan dan pemecahan [11]. Untuk mengetahui berhasil atau tidaknya proses pembelajaran maka diadakan evaluasi dengan menggunakan tes.

Indonesia belum banyak yang mengenal platform ini. Schoology adalah jaringan sosial untuk K-12 (sekolah menengah) dan lembaga pendidikan tinggi difokuskan pada kerja sama, yang memungkinkan pengguna untuk membuat, mengelola, dan berbagi konten akademis. Juga dikenal sebagai sistem manajemen pembelajaran (LMS) atau sistem manajemen kursus (CMS), platform berbasis cloud menyediakan peralatan yang diperlukan untuk mengelola sebuah kelas online [12]. Schoology dirilis secara komersial pada bulan Agustus 2009 dan itu mirip dengan facebook. Ini adalah sebuah platform online yang menggabungkan media sosial dan prinsip-prinsip sistem manajemen kelas elektronik dan terlihat seperti facebook. Antar muka tidak asing bagi sebagian besar siswa dan fitur dasar bebas. Dengan demikian, schoology memungkinkan untuk membuat tugas, peristiwa, tes dan kuis. Sangat mudah melalui alat ini untuk mengelola buku kelas dan kehadiran dan untuk melacak penggunaan dan program analisis siswa. Fitur sosial yang sangat akrab dan dekat dengan facebook seperti blog dengan halaman profil.

Schoology memiliki konsep yang sama dengan LMS dan social networking. Schoology memiliki fitur yang nyaris sama dengan facebook seperti gambar di bawah ini.

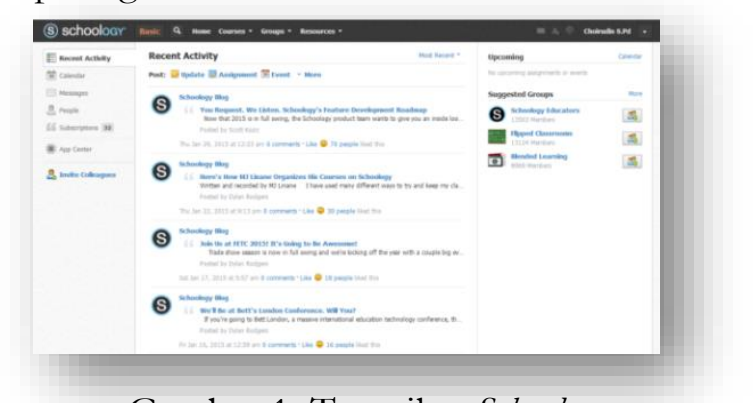

Gambar 1. Tampilan Schoology

Ni Wyn Schoology merupakan salah satu LMS berbentuk web sosial yang menawarkan pembelajaran sama seperti di dalam kelas secara percuma (gratis) dan mudah digunakan seperti media sosial facebook [1]. Bagi para pengguna facebook, tidak akan mengalami kesulitan ketika menjelajahi fitur schoology. Meski tidak memiliki warna yang sama dengan facebook, namun fiturnya sangat mirip dengan fitur facebook. Schoology juga menggunakan istilah-istilah yang biasa kita gunakan pada facebook seperti recent activity, messeges, course, resource, groups, assignment, attendance dan seterusnya.

Schoology menawarkan lebih dari sekedar faktor facebook. Ini adalah sistem manajemen pembelajaran yang kuat dengan aplikasi yang tersedia untuk perangkat mobile pad, iphone, android, dan kindle. Siswa menemukan bahwa mengirimkan tugas, mengambil tes, membuat komentar, dan mengajukan pertanyaan yang halus dan intuitif bagi mereka, dan mereka mempertahankan akses ke sumber daya dalam kursus mereka setelah berakhir semester [13].

Pada schoology, library serupa dengan my resources. Berikut tampilannya: 


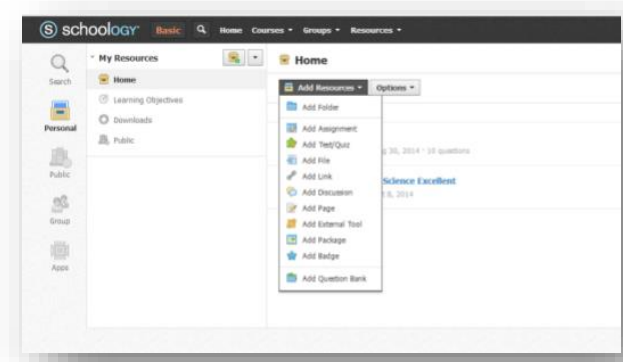

Gambar 2. Tampilan my resource pada schoology

Kelebihan lain schoology adalah tersedianya fasilitas 55ttendance/absensi, yang digunakan untuk mengecek kehadiran peserta didik, dan juga fasilitas analityc untuk melihat semua aktivitas peserta didik pada setiap course, assignment, discussion dan aktivitas lain yang kita siapkan untuk peserta didik. Melalui fitur analytic ini, kita juga bisa melihat di mana saja atau pada aktivitas apa saja seorang peserta didik biasa menghabiskan waktu mereka ketika $\log$ in.

kita bisa melakukan pengaturan/moderasi terhadap user yang ingin gabung pada group/kelas, pada status access group sebagai invite only, allow requests ataupun open. Kita juga bisa memfilter postingposting peserta didik pada sebuah course sebelum postingan dipublish. Jadi peserta didik tidak bisa seenaknya update status pada course-nya [14].

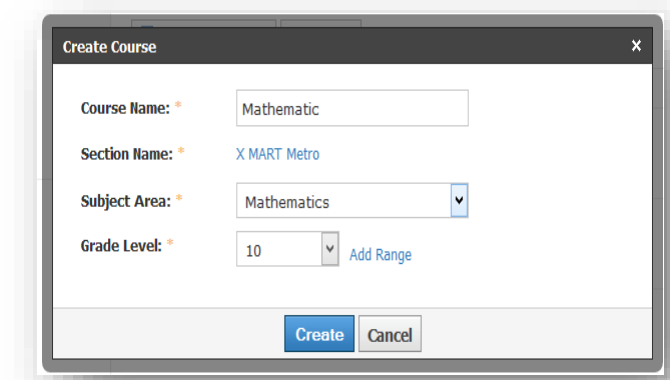

Gambar 3. Tampilan course pada schoology

Selain posting (update status), schoology juga menyediakan fasilitas blog untuk memfasilitasi user yang ingin melakukan posting blog pada account schoology-nya. Secara khusus schoology juga memiliki fasilitas untuk berkirim surat/message dan hanya melalui direct post, maka pada schoology bisa berkirim surat kemanapun melalui fasilitas messages yang tersedia.

Schoology juga tidak hanya bisa mengupdate status schoology untuk course atau group anda saja, melainkan anda juga bisa mengintegrasikan (sharing) postingan ke account facebook atau twitter.

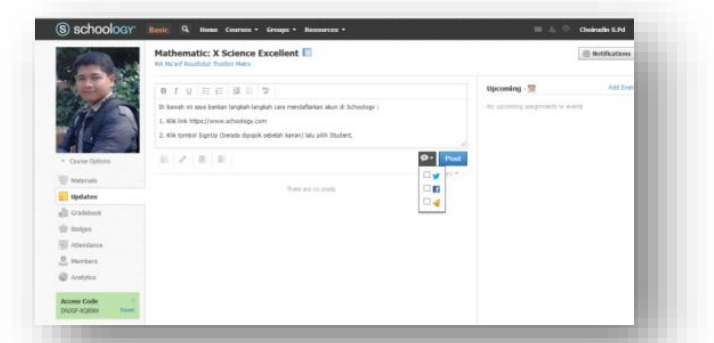

Gambar 3. Tampilan course pada schoology 
The facility for interactive communication permits teachers to create discussion questions, collaborative groups for assignments that allow some kind of dynamic interaction among the in-service teachers and their teachers. As for the second aspect of academic information exchange, Schoology provides the in-service teachers the opportunity to access their grades, attendance records, and teacher feedback on electronically-submitted assignments. In short, via Schoology, a range of different E-learning tasks and assessments were included to complement the traditional intensive face-to-face meetings. [15]

Fasilitas untuk komunikasi interaktif memungkinkan guru untuk membuat pertanyaan diskusi, kelompok kolaboratif untuk tugas yang memungkinkan beberapa jenis interaksi yang dinamis antara inservice guru dan guru-guru mereka. Adapun aspek kedua pertukaran informasi akademik, Schoology menyediakan in-service guru kesempatan untuk mengakses nilai-nilai mereka, catatan kehadiran, dan umpan balik guru pada tugas elektronik yang dikirimkan. Singkatnya, melalui Schoology, berbagai Elearning tugas dan penilaian yang berbeda dimasukkan untuk melengkapi intensif pertemuan tatap muka tradisional.

Schoology juga menyediakan fasilitas untuk mengelola nilai (grade) hasil quis atau aktivitas lain, via Gradebook. Schoology juga bisa diakses melalui mobile device, dengan menginstal Schoology Apps, yang bisa didownload dan gunakan secara gratis.

Dapat disimpulkan bahwa di dalam Schoology ini sangatlah lengkap dengan berbagai alat pembelajaran, sama seperti di kelas dalam dunia nyata, mulai dari absensi, tes dan kuis hingga kotak untuk mengumpulkan pekerjaan rumah. Yang lebih hebat, Schoology menawarkan jejaring lintas sekolah, yang memungkin sekolah berkolaborasi dengan berbagi data, kelompok dan juga diskusi kelas. Schoology sangat cocok sebegai media pembelajaran dalam E-learning.

Dalam mengembangkan pembelajaran media E-learning yang berbasis Schoology, digunakan pembelajaran model EDDIE[1]. Pemilihan model ini didasari atas pertimbangan bahwa model ini mudah untuk dipahami, selain itu juga model ini dikembangkan secara sistematis dan berpijak pada landasan teoretis desain pembelajaran yang dikembangkan. Model ini disusun secara terprogram dengan kegiatan yang sistematis dalam upaya pemecahan masalah belajar yang berkaitan dengan media belajar yang sesuai dengan kebutuhan dan karakteristik siswa.

Tegeh menyatakan tahapan penelitian pengembangan pada model ADDIE yaitu: (1) Analis (Analysis), (2) Desain/perancangan (Design), (3) Pengembangan (Development), (4) Implementasi atau eksekusi (Implementation), dan (5) Evaluasi/umpan balik (Evaluation)[16].

Keterampilan adalah kemampuan melakukan pola-pola tingkah laku yang komplek dan tersusun rapi secara mulus dan sesuai keadaan untuk mencapai hasil tertentu, keterampilan bukan hanya meliputi gerakan motorik melainkan juga pengejawantahan fungsi mental yang bersifat kognitif. Sedangkan proses berarti cara-cara atau langkah-langkah khusus beberapa perubahan yang menimbulkan tercapainya hasil tertentu[17].

Pendekatan keterampilan proses dapat diartikan sebagai wawasan atau aturan pengembangan keterampilan-keterampilan intelektual, sosial dan fisik yang bersumber dari kemampuan-kemampuan mendasar yang pada prinsipnya telah ada dalam diri siswa[18]. Dari batasan pendekatan keterampilan proses tersebut kita mempunyai suatu gambaran bahwa keterampilan proses bukanlah tindakan instruksional yang berada di luar kemampuan siswa. Justru keterampilan proses dimaksudkan untuk mengembangkan kemampuan-kemampuan yang dimiliki oleh siswa karena: 
(a) Keterampilan proses memberikan pengertian yang tepat kepada siswa tentang hakikat ilmu pengetahuan. Siswa dapat mengalami rangsangan ilmu pengetahuan dan dapat lebih baik mengerti fakta dan konsep ilmu pengetahuan.

(b) Mengajar dengan keterampilan proses berarti memberi kesempatan kepada siswa bekerja dengan ilmu pengetahuan, tidak sekedar menceriterakan atau mendengar cerita tentang ilmu pengetahuan. Di sisi yang lain, siswa merasa bahagia sebab mereka aktif dan tidak menjadi pelajar yang pasif.

(c) Menggunakan keterampilan proses untuk mengajar ilmu pengetahuan, membuat siswa belajar proses dan produk ilmu pengetahuan sekaligus.

Keaktifan belajar menurut Sardiman adalah aktifitas yang bersifat fisik maupun mental[19]. Selama proses belajar siswa dituntut aktivitasnya untuk mendengarkan, memperhatikan dan mencerna pelajaran yang diberikan guru, disamping itu sangat dimungkinkan para siswa memberikan balikan berupa pertanyaan, gagasan pikiran, perasaan, keinginannya. Guru hendaknya mampu membina rasa keberanian, keingintahuan siswa, untuk itu siswa hendaknya merasa aman, nyaman, dan kondusif dalam belajar. Peran guru dalam pembelajaran siswa aktif adalah sebagai fasilitator dan pembimbing siswa yang memberi berbagai kemudahan siswa dalam belajar serta mampu mendorong siswa untuk belajar seoptimal mungkin.

Keaktifan yang dilakukan siswa selama proses pembelajaran memiliki pengaruh yang berbedabeda terhadap daya ingat siswa. Anni dalam penelitiannya menemukan bahwa ingatan yang diperoleh dari belajar melalui membaca sebesar 20\%, mendengar sebesar 30\%, melihat sebesar 40\%, mengucapkan sebesar 50\%, melakukan sebesar 60\%, dan gabungan dari melihat, mengucapkan, mendengar, dan melakukan sebesar 90\%[20].

Proses belajar-mengajar yang dapat memungkinkan cara belajar siswa secara aktif harus direncanakan dan dilaksanakan secara sistematik. Selama pelaksanaan belajar-mengajar hendaknya diperhatikan beberapa prinsip, seperti stimulus, perhatian dan motivasi, respons yang dipelajari, penguatan, dan pemakaian dan pemindahan sehingga siswa dapat belajar dengan optimal.

\section{METODE PENELITIAN}

Metode penelitian yang digunakan dalam penelitian ini adalah metode eksperimen semu (quasiexperimental research). Hal ini dikarenakan peneliti tidak memungkinkan untuk mengendalikan dan memanipulasi semua variabel yang relevan. Seperti yang dikemukakan Budiyono bahwa tujuan eksperimental semu adalah untuk memperoleh informasi yang merupakan perkiraan bagi informasi yang dapat diperoleh dengan eksperimen yang sebenarnya dalam keadaan yang tidak memungkinkan untuk mengontrol atau memanipulasi semua variabel yang relevan[21]. Pada penelitian ini yang dilakukan adalah membandingkan hasil belajar dari kelompok eksperimen yang menggunakan E-learning Schoology dengan kelompok kontrol yang menggunakan metode konvensional materi pokok persamaan kuadrat.

Desainnya menggunakan randomized posttest design only. Adapun desain penelitiannya menurut Arikunto adalah sebagai berikut [22]:

Tabel 1. Desain Penelitian

\begin{tabular}{ccc}
\hline Kelompok & Treatment & Posttest \\
\hline Eksperimen & $\mathrm{X}_{1}$ & $\mathrm{Y}_{1}$ \\
\hline Copyright (C) 2017, Numerical: Jurnal Matematika dan Pendidikan Matematika \\
Print ISSN: 2580-3573, Online ISSN: 2580-2437
\end{tabular}




\begin{tabular}{lll}
\hline Kontrol & $\mathrm{X}_{2}$ & $\mathrm{Y}_{2}$ \\
\hline
\end{tabular}

\section{Keterangan:}

$\mathrm{X}_{1}:$ pembelajaran e-learning

$\mathrm{X}_{2}$ : pembelajaran konvensional

$\mathrm{Y}_{1}$ : hasil belajar e-learning

$\mathrm{Y}_{2}$ : hasil belajar konvensional

\section{HASIL DAN PEMBAHASAN}

Pembelajaran e-learning berbasis schoology pada pembelajaran matematika dikatakan efektif apabila: (a) dapat membuat hasil belajar matematika siswa mencapai kriteria ketuntasan belajar minimal; (b) menunjukkan adanya pengaruh yang signifikan antara keterampilan proses terhadap hasil belajar matematika siswa dapat membuat mencapai kriteria minimal klasifikasi baik; (c) menunjukkan adanya pengaruh yang signifikan keaktifan siswa terhadap hasil belajar matematika siswa dapat membuat mencapai kriteria minimal klasifikasi baik, dan (d) dapat menunjukkan hasil belajar matematika peserta didik yang belajar dengan e-learning schoology lebih baik dari pembelajaran konvensional pada materi persamaan kuadrat.

Hasil tes hasil belajar siswa pada materi persamaan kuadrat diketahui nilai tertinggi 100; nilai terendah 50; rata-rata 76,75. Dengan nilai tertinggi 100, nilai terendah 50; dan rata-rata 76,75; menunjukkan rata-rata hasil belajar sudah melebihi KKM (70); namun masih terdapat siswa yang belum mencapainya. Dengan nilai median 80,00 menunjukkan bahwa terdapat setengah jumlah siswa eksperimen sudah mendapat nilai lebih besar dari 80,00 dan setengahnya masih berada di bawah 80,00. Diperolehnya modus 80 menunjukkan bahwa kebanyakan siswa kelas eksperimen mendapat nilai 80 . Selanjutnya dengan mengurangi dan menambah nilai rata-rata dengan dua kali simpangan baku 80,00 $2 \times 15,413=49,174$ dan 80,00 $+2 \times 15,413=110,826$ nilai tersebut di bawah rentang dan melebihi nilai maksimum 100 dan nilai minimal 50, masih dalam interval tersebut. Hal ini menunjukkan bahwa jawaban siswa bersifat heterogen, atau tidak berkumpul sehingga dapat diduga bahwa dalam pelaksanaan tes tidak terjadi kecurangan, terutama kerja sama dalam mengerjakan soal.

Berdasarkan tes hasil belajar siswa pada materi persamaan kuadrat dapat diketahui nilai tertinggi 100; nilai terendah 50; rata-rata 70,23. Dengan nilai tertinggi 100, nilai terendah 50; dan rata-rata 70,23; menunjukkan rata-rata hasil belajar sudah melebihi KKM (70); namun masih terdapat siswa yang belum mencapainya. Dengan nilai median 70,00 menunjukkan bahwa terdapat setengah jumlah siswa eksperimen sudah mendapat nilai lebih besar dari 70,00 dan setengahnya masih berada di bawah 70,00. Diperolehnya modus 70 menunjukkan bahwa kebanyakan siswa kelas kontrol mendapat nilai 70 . Selanjutnya dengan mengurangi dan menambah nilai rata-rata dengan dua kali simpangan baku 70,00 $2 \times 12,675=44,65$ dan 70,00 $+2 \times 12,675=95,35$ nilai tersebut di bawah rentang dan kurang nilai maksimum 100 dan lebih dari nilai minimal 50.

Pengambilan data keterampilan proses juga hanya dilakukan pada kelas eksperimen. Berdasarkan hasil pengamatan keterampilan proses diketahui skor tertinggi 46, terendah 29; rata-rata 36,90 .

Pengambilan data keaktifan hanya pada kelas eksperimen. Hasilnya dapat dideskripsikan skor tertinggi 90, terendah 75, rata-rata 81,83. Pembelajaran e-learning schoology dapat membuat hasil belajar matematika siswa materi persamaan kuadrat mencapai kriteria ketuntasan belajar. Untuk menguji hipotesis ini digunakan uji beda rata-rata satu sampel. Kriteria ketuntasan belajar minimal yang 
ditetapkan adalah 70. Berdasarkan perhitungan pengujian hipotesis pertama didapat output t-tes di atas menunjukkan nilai $\mathrm{t}=22,269$ dan sig $=0,000$ kurang dari 5\%, maka Ho ditolak, artinya rata-rata hasil belajar matematika kelas eksperimen tidak sama dengan 70 . Karena rata-rata hasil belajar matematika siswa kelas eksperimen (76,75) melebihi nilai 70, maka sesuai dengan hipotesis pertama kita dapatkan jawaban hipotesis bahwa dengan pembelajaran e-learning schoology dapat mencapai ketuntasan belajar.

Pengujian hipotesis kedua, bertujuan untuk mengetahui bahwa, keterampilan proses dalam pembelajaran e-learning schoology pada materi persamaan kuadrat kelas X IPA 1 berpengaruh positif terhadap hasil belajar siswa. Untuk menguji kelinearan lihat tabel out put coefficients didapatkan persamaan regresi $\hat{Y}=22,994+1,457 \mathrm{X}$ dengan hipotesis: Ho $=$ coefficiens regresi tidak signifikan. Ha $=$ coefficiens regresi signifikan. $\mathrm{t}$ hitung $(2,394)>\mathrm{t}$ tabel $(18 ; 0,05)$ 1,734, maka Ho ditolak. Jadi koefisien regresi signifikan, begitu pula dengan Sig $(0,028)<\alpha(0,05)$, maka Ho ditolak. Jadi koefisien regresi signifikan, artinya persamaan regresi linear. Selanjutnya alasan untuk menerima atau menolak hipotesis disajikan Anova Sig $=0,028=2,8 \%$ lebih kecil dari 5\%, maka Ho diterima dan persamaan regresi linear. Untuk melihat besar kontribusi keaktifan siswa terhadap hasil belajar dilihat pada nilai $R$ square sebesar 0,242= $24,2 \%$ hal ini positif, sesuai dengan hipotesis kedua. Dengan demikian keterampilan proses dalam pembelajaran e-learning schoology pada materi persamaan kuadrat kelas X IPA 1 berpengaruh positif terhadap hasil belajar siswa.

Pengujian hipotesis ketiga: keaktifan siswa dalam pembelajaran e-learning schoology pada materi persamaan kuadrat kelas X IPA $\mathrm{PA}_{1}$ mencapai ketuntasan belajar, menggunakan analisis regresi, dengan membaca tabel persamaan regresi $\hat{Y}=24,658+1,344 \mathrm{X}$ dengan hipotesis : Ho $=$ coefficiens regresi tidak signifikan. $\mathrm{Ha}=$ coefficiens regresi signifikan. $\mathrm{t}$ hitung $(2,106)>\mathrm{t}$ tabel $(18 ; 0,05) 1,734$, maka Ho ditolak. Jadi koefisien regresi signifikan, begitu pula dengan Sig $(0,045)<\alpha(0,05)$, maka Ho ditolak. Jadi koefisien regresi signifikan, artinya persamaan regresi linear. Selanjutnya alasan untuk menerima atau menolak hipotesis disajikan tabel Anova Sig $=0,045=4,5 \%$ lebih kecil dari 5\%, maka Ho diterima dan persamaan regresi linear. Sedangkan untuk melihat besar kontribusi keterampilan proses terhadap hasil belajar $r$ square sebesar 0,198 = 19,8\% hal ini positif, sesuai dengan hipotesis kedua. Dengan demikian keaktifan siswa dalam pembelajaran e-learning schoology pada materi persamaan kuadrat kelas X IPA berpengaruh positif terhadap hasil belajar siswa.

Selanjutnya untuk melihat pengaruh keterampilan proses dan keaktifan siswa terhadap hasil belajar secara bersama-sama kita perlu melakukan : (i). Uji Normalitas, data yang di uji hanya variabel dependen $\mathrm{Y}$, karena hanya variabel $\mathrm{Y}$ yang merupakan fungsi distribusi dan dapat diuji distribusi normalitasnya, sedangkan variabel lainnya tidak, karena diasumsikan bukan merupakan fungsi distribusi[23]. Salah satu uji normalitas yang tersedia dalam SPSS adalah uji Kolmogorov-Smirnov sig 0,349 yang lebih besar dari 5\%, sehingga Ho tidak ditolak (diterima). Hal ini berarti variabel Y berdistribusi normal.

Pengujian hipotesis keempat, yaitu: Hasil belajar siswa pada pembelajaran e-learning schoology pada materi persamaan kuadrat kelas X lebih baik dari pada pembelajaran konvensional, digunakan uji beda rata-rata dua sampel, karena dalam penelitian ini yang dijadikan sebagai kelas eksperimen, dan yang jadi kelas kontrol. Uji beda rata-rata dilakukan terhadap kedua kelas dengan bantuan SPSS diperoleh t-tes di atas pada kolom Levene's test for equality of variances menunjukkan nilai $\mathrm{F}=1,564$ dan sig $=0,218$ lebih dari 5\% maka Ho diterima, artinya variansi hasil belajar siswa kelas eksperimen dan kelas kontrol adalah sama. Dengan memilih asumsi memiliki varians yang sama (equal variance's assumed) diperoleh nilai sig = 0,141 yang nilainya lebih besar dari 5\%, sehingga Ho ditolak, kesimpulannya terdapat perbedaan hasil belajar kelas eksperimen dan hasil belajar kelas kontrol. Karena rata-rata hasil belajar kelas eksperimen 
$(76,75)$ dengan rata-rata nilai kelas kontrol $(70,23)$. Hal ini mendukung terbuktinya hipotesis empat yang menyatakan: Hasil belajar siswa pada pembelajaran e-learning schoology pada materi persamaan kuadrat kelas X lebih baik dari pada pembelajaran konvensional.

Dari uraian di atas, imbas dari penelitian ini adalah kepada guru. Sebagai fasilitator yang harus selalu menciptakan lingkungan belajar yang kondusif, dari mulai ruang kelas sampai suasana belajar yang aktif kreatif dan menyenangkan. Guru harus pandai memilih pendekatan yang tepat untuk setiap materi yang akan disajikan. Dengan pembelajaran e-learning melalui media schoology materi yang disajikan akan membangkitkan aktifitas anak untuk bersaing dengan temannya, dan ikut aktif memecahkan masalah yang disajikan guru.

Hal ini sesuai dengan pendapat Ni Wyn yang dikemukakan selain kemudahan-kemudahan yang diberikan kepada peserta didik, dengan berbagai fasilitas yang dimiliki schoology guru juga dapat membuat atau memberikan materi pelajaran, kuis, tugas dan penilaian langsung kepada peserta didik [1]. Guru juga diberikan kewenangan mutlak di dalam mengolah dan mengatur jalannya aktivitas kelas di dalam schoology. Siswa yang diberi kewenangan dituntut untuk dapat mandiri dalam belajar. Menurut Ningsih dengan kemandirian belajar siswa dapat menemukan sumber-sumber belajar lain yang dapat mendukung kegiatan belajar [24]. Peserta didik tidak dapat seenaknya sendiri melakukan aktivitas di luar aktivitas pembelajaran karena guru dapat menghapus peserta didik dari kelas atau sementara waktu menonaktifkannya. Dengan pengaturan kelas yang baik dan penyediaan materi pembelajaran yang berbobot serta menarik maka peserta didik akan bersemangat dan bertanggung jawab dalam setiap pembelajaran di dalam schoology. Sehingga pembelajaran e-learning melalui media schoology dapat menjadi salah satu pembelajaran yang efektif bagi siswa.

\section{SIMPULAN DAN SARAN}

Pembelajaran e-learning schoology pada materi persamaan kuadrat kelas X mencapai ketuntasan belajar minimal $(\mathrm{KKM}=70)$. Keterampilan proses pada pembelajaran e-learning schoology berpengaruh positif terhadap hasil belajar siswa. Keaktifan siswa pada pembelajaran e-learning schoology berpengaruh positif terhadap hasil belajar. Hasil belajar siswa pada pembelajaran E-learning Schoology pada materi persamaan kuadrat kelas X lebih baik dari pada pembelajaran konvensional. Dengan diterimanya keempat hipotesis penelitian ini, membuktikan bahwa pembelajaran e-learning schoology di MA Ma'arif Roudlotut Tholibin Metro efektif.

Penggunaan e-learning schoology bukan pembelajaran sederhana dan mudah dalam pelaksanaannya. Untuk itu, perlu dilakukan pengembangan media pada materi secara keseluruhan sehingga meningkatkan kualitas materi yang dikembangkan. Pengembangan media pembelajaran yang lebih lanjut perlu ditambahkan lagi animasi-animasi yang lebih menarik, disesuaikan dengan materi.

\section{DAFTAR PUSTAKA}

[1] Ni Wyn, Mei Ananda Putri, Nyoman Jampel, and I Kadek Suartama, "Pengembangan E-Learning Berbasis Schoology," J. Edutech Univ. Pendidik. Ganesha Jur. Teknol. Pendidik, vol. 2, no. 1, 2014.

[2] Santi Widyawati, Mardiyana, and Gatut Iswahyudi, "Eksperimentasi Model Pembelajaran Kooperatif Tipe Two Stay Two Stray (TSTS) dan Numbered Heads Together (NHT) Ditinjau dari Kecerdasan Majemuk Peserta Didik," J. Elektron. Pembelajaran Mat., vol. 2, no. 9, pp. 972-983, 2014.

[3] Hidayati, N., "Sistem E-Learning Untuk Meningkatkan Proses Belajar Mengajar: Studi Kasus Pada Sma Negeri 10 Bandar Lampung," J. Telematika MKom, vol. 2, no. 2, 2010. 
[4] Yazdi, M., "E-Learning Sebagai Media Pembelajaran Interaktif Berbasis Teknologi Informasi," J. Ilm. Foristek, vol. 2, no. 1, Mar. 2012.

[5] C. Choirudin, "Efektifitas Pembelajaran Matematika Dengan E-Learning Berbasis Schoology," masters, Universitas Terbuka, 2015.

[6] Aldrich, Clark., Learning Online with Games, Simulations, and VirtualWorlds: Strategies for Online Instruction. USA: IGI Globa, 2010.

[7] Moeng, B., "IBM Tackles Learning in the Workplace." .

[8] The American Society for Training and Development/ASTD, "Definition of e-Learning," 2012. .

[9] Prasojo diat. L., "Model Pembelajaran Berbasis E Learning Pada Prodi Manajemen Pendidikan Fakultas Ilmu Pendidikan Universitas Negeri Yogyakarta," Universitas Negeri Yogyakarta, Yogyakarta, 2010.

[10] E. F. Ningsih, "Proses Berpikir Mahasiswa Dalam Pemecahan Masalah Aplikasi Integral Ditinjau Dari Kecemasan Belajar Matematika (Math Anxiety)," J. IQRA, vol. 1, no. 2, pp. 191-217, 2017.

[11] A. P. Maba, "Paradoxical intervention dalam bimbingan dan konseling untuk mengatasi kecemasan,” Couns. J. Bimbing. Dan Konseling, vol. 7, no. 2, pp. 99-109, 2017.

[12] Mchichi, T. and Afdel, Karim, "Exploiting Web 2.0 Technologiesin PromotingLearning ActivitiesE-learning - Web 2.0 Platform," ISESCO J. Sci. Technol., vol. 8, no. 14, pp. 13-18, Nov. 2012.

[13] Alvin S. Sicat, “Enhancing College Students' Proficiency in Business Writing Via Schoology," Int. J. Educ. Res., vol. 3, no. 1, Jan. 2015.

[14] Biswas. S., "Schoology-Supported Classroom Management: A Curriculum Review," J. Fall, vol. 11, no. 2, p. 188, 2013.

[15] Kean Wah, L., Choon Keonga, T., and Denis, Shi Ing, N., "Understanding the Blended Learning Experiences of English Language Teachers in a Distance TESL Degree Programme in Malaysia," J. Teknol. Soc. Sci., vol. 65, no. 2, 2013.

[16] Tegeh, I Made and I Made Kirna, Metode Penelitian Pengembangan Pendidikan. Singaraja: Undiksha, 2010.

[17] Syah. M., Psikologi Belajar. Jakarta: PT. Raja Grafindo Persada, 2013.

[18] Depdikbud, Penelitian Tindakan Kelas (PTK) Tentang Efektivitas Pembelajaran Kelas. Yogyakarta: IKIP, 2006.

[19] Sardiman, Interaksi dan Motivasi Belajar Mengajar. Bandung: Rajawali Pers, 2015.

[20] Anni, TC., Psikologi Belajar. Semarang: UNNES Press, 2014.

[21] Budiyono, Statistika untuk Penelitian, 2nd ed. Surakarta: Sebelas Maret University Prees, 2014.

[22] S. Arikunto, Prosedur Penelitian Suatu Pendekatan Praktik. Suharsimi: Rineka Cipta, 2013.

[23] Sukestiyarno, Instrumen dan Analisis Data Penelitian. Semarang: Diktat kuliah Statistika PPS UNNES, 2012.

[24] E. F. Ningsih and G. Iswahyudi, "Eksperimentasi Model Pembelajaran Kooperatif Tipe Team Assisted Individualization (Tai) Dengan Metode Snowball Drilling Terhadap Prestasi Belajar Matematika Ditinjau Dari Kemandirian Belajar," 2014. 
Numerical: Jurnal Matematika dan Pendidikan Matematika, Vol. 1 No. 2 Desember, 52-62 Choirudin

[Halaman ini sengaja dikosongkan] 